Reprod. Nutr. Dévelop., 1985, 25 (2), 367-377.

\title{
Production of seminiferous and interstitial fluid in the growing rat after unilateral testicular irradiation
}

\author{
P. LAPORTE, O. LE FLOCH (*)
}

Station de Physiologie de la Reproduction, I.N.R.A., Nouzilly, 37380 Monnaie, France.

(*) C.H.U. "Bretonneau ", Service de Radiothérapie, 37044 Tours Cedex, France.

Summary. The production of tubular fluid (TF) and interstitial fluid (IF) in normal and irradiated testes was compared in the same growing rats submitted at 25 days of age to unilateral, scrotal X-ray, exposure. Twelve rats were sacrificed each week from 32 to 81 days of age. In both normal and irradiated testes, IF increased in parallel with the testicular weight until 67 days of age and declined slightly thereafter. TF secretion of normal testes increased significantly until 53 days of age, declined significantly until 67 days, and stabilized thereafter. A similar pattern of TF secretion was observed for irradiated testes but with a greater production between days 32 and 46, a lower maximal level at day 53 and a lower but non-significant level from day 67 onwards. All these observations combined with previous results led us to suggest (1) the quantitative influence of germ cells on both TF and IF secretion, (2) the stimulatory effect of diploid germ cells (spermatogonia) and (3) the inhibitory effect of haploid germ cells (probably spermatids) on Sertoli cell secretion. The latter qualitative influence seemed preponderant in adulthood.

\section{Introduction.}

After both busulfan treatment (Laporte and Gillet, 1975) and testicular irradiation (Laporte et al., 1985) in adult rats, we observed an inverse relationship between spermatogenesis and tubular fluid secretion, that is to say that in the absence of germinal cells (or when the germinal cell population was depleted), fluid production was higher than when the germinal cell population was normal. In view of the lack of any peripheral hormone changes, these results suggested local germ cell inhibition of Sertoli cell fluid secretion. On the contrary, it is well established that testicular fluid secretion in pubertal rats increases when spermatogenesis is developing (Setchell, 1970 ; Laporte, 1979 ; Jegou et al., 1982 ; Laporte and Gillet, 1984), with a maximal secretion between 50 and 60 days of age. Beyond this period, the secretion decreases regularly to adult levels which reach a plateau by about 75 days of age (Laporte, 1979). These apparently contradictory observations led us to suppose that the germ cell line might locally 
influence the somatic cell line in several ways; these effects cannot be observed in adult rats but might possibly be seen during pubertal development when spermatogenesis is being established. In the present work, we compared the changes in the pattern of tubular and interstitial fluid production in both testes of growing rats. In these rats the right testis was X-irradiated while the left testis, which was not, served as a control.

\section{Material and Methods.}

Animals. - After weaning at 23 days of age, 96 male Wistar rats were randomly housed in groups of 6 animals in cages under controlled light $(14 \mathrm{~L}$ : 10D) and temperature $\left(+22^{\circ} \mathrm{C}\right)$. A special UAR diet and tap water were given ad libitum.

Irradiation and surgical procedures. - At 25 days of age, all rats were individually and slightly anaesthetized with ether and restrained by hand on a plastic support in a prone position. The right scrotal area was exposed to irradiation by a special medical X-ray machine used for contact therapy. The right testis was subjected to a total dose of $1 \mathrm{~Gy}$ delivered in a 6-sec period. The rats were sacrificed by decapitation in groups of 12 . The first group was sacrificed at 32 days of age and subsequent groups at weekly intervals up to 81 days. Twentyfour hours before sacrifice the rats were anaesthetized with ether for a period of 10 min. In 6 rats of each group (subgroup 1), the right testis was ligated and the left testis removed and immediately weighed, while in the six remaining rats (subgroup 2), the reverse procedure was performed. At sacrifice, the remaining testis was removed and immediately weighed. The ventral prostate and seminal vesicles of each rat were also dissected out and weighed. All testes were lyophilised together for 48 hours and the dry weight measured. Table 1 summarizes the experimental design.

Tubular fluid accumulation in ligated testes. - TF was determined by the difference between true water content following 24-hour efferent duct ligation

TABLE 1

Experimental design used for testicular fluid (TF) determination and interstitial fluid (IF) collection from normal and irradiated testes.

\begin{tabular}{|c|c|c|c|c|c|}
\hline \multirow{2}{*}{ Treatment } & \multirow{2}{*}{$\begin{array}{l}\mathrm{N}^{\circ} \\
\text { of } \\
\text { rats }\end{array}$} & \multicolumn{2}{|c|}{ Status of testes } & \multirow{2}{*}{$\begin{array}{l}\text { Testes used } \\
\text { for } \\
\text { IF collection }\end{array}$} & \multirow{2}{*}{$\begin{array}{l}\text { Testes used } \\
\text { for TF } \\
\text { determination }\end{array}$} \\
\hline & & Right & Left & & \\
\hline Unilateral irradiation & $\begin{array}{l}48 \\
48\end{array}$ & $\begin{array}{l}(\bullet) \mathrm{I}-\mathrm{li} \\
(\bullet) 1\end{array}$ & $\begin{array}{l}(\bullet) N \\
(\bullet) N-l i\end{array}$ & $\begin{array}{l}(\bullet) N \\
(\bullet) 1\end{array}$ & $\begin{array}{c}(\bullet) \mathrm{I}-\mathrm{i} \text { and }(\bullet) \mathrm{I} \\
(\bullet \bullet) \mathrm{N}-\mathrm{Ii} \text { and }(\bullet \bullet) \mathrm{N}\end{array}$ \\
\hline
\end{tabular}

$\mathrm{I}, \mathrm{N}$ and li : signify respectively : irradiated, normal and ligated testis.

$(\bullet)$ and $(\bullet \bullet)$ : IF and TF determinations in groups with testes from different rats. 
and supposed water content of the same testis before ligation by a method previously described (Laporte et al., 1985) and summarized in table 2.

\section{TABLE 2}

Method of TF determination

\section{Parameters :}

- True water content of testis (mg).

Wet wgt - Dry wgt.

- True water concentration of testis $(\mathrm{mg} / \mathrm{mg}$ of dry testis wgt.).

True water content : Dry wgt of testis parenchyma.

- Supposed water content of ligated testis before ligation $(\mathrm{mg})$.

Mean of true water concentration of unligated testes $\times$ Dry wgt of parenchyma of ligated testis.

TF estimation of ligated testis (in $\mathrm{mg} / 24 \mathrm{~h}$ ) :

True water content (after ligation) - Supposed water content (before ligation).

Interstitial fluid collection and water concentration of unligated testes. - IF was measured by the method of Sharpe (1977) by collecting the lymph for 24 hours at $4{ }^{\circ} \mathrm{C}$ from the incised caudal end of the unligated testes. Thereafter the dry weight of the albuginea and the parenchyma of these testes were determined and the true water concentration calculated.

Statistical analysis. - The data are presented as the mean \pm SEM. The significance of the differences between irradiated and protected testes at each age was assessed by Student't-test.

\section{Results.}

Body, testicular and accessory sexual organ weights. - As shown in table 3 , body weight and the weights of the seminal vesicles and prostate increased

TABLE 3

Age changes in body weight and accessory sexual organ weight of rats randomly allotted to two groups after unilateral testis irradiation (mean \pm SEM, 6 rats per group).

\begin{tabular}{|c|c|c|c|c|c|c|}
\hline \multirow{2}{*}{$\begin{array}{l}\text { Age } \\
\text { in } \\
\text { days }\end{array}$} & \multicolumn{2}{|c|}{$\begin{array}{l}\text { Body weight } \\
\text { (g) }\end{array}$} & \multicolumn{2}{|c|}{$\begin{array}{l}\text { Seminal vesicle wgt. } \\
\text { (mg) }\end{array}$} & \multicolumn{2}{|c|}{$\begin{array}{l}\text { Ventral prostate wgt. } \\
\text { (mg) }\end{array}$} \\
\hline & Gr. 1 & Gr. 2 & Gr. 1 & Gr. 2 & Gr. 1 & Gr. 2 \\
\hline $\begin{array}{l}32 \\
39 \\
46 \\
53 \\
60 \\
67 \\
74 \\
81\end{array}$ & $\begin{aligned} & 86 \pm 5 \\
& 141 \pm 7 \\
& 189 \pm 4 \\
& 214 \pm 7 \\
& 242 \pm 11 \\
& 286 \pm 3 \\
& 308 \pm 7 \\
& 344 \pm 10\end{aligned}$ & $\begin{array}{r}83 \pm 5 \\
134 \pm 4 \\
181 \pm 6 \\
224 \pm 5 \\
242 \pm 4 \\
267 \pm 13 \\
319 \pm 10 \\
314 \pm 5\end{array}$ & $\begin{array}{c}13 \pm 1 \\
29 \pm 3 \\
75 \pm 7 \\
192 \pm 11 \\
394 \pm 33 \\
505 \pm 21 \\
606 \pm 40 \\
710 \pm 24\end{array}$ & $\begin{array}{c}13 \pm 1 \\
29 \pm 3 \\
70 \pm 7 \\
247 \pm 34 \\
370 \pm 22 \\
444 \pm 33 \\
635 \pm 32 \\
670 \pm 34\end{array}$ & $\begin{array}{r}52 \pm 3 \\
60 \pm 3 \\
92 \pm 9 \\
125 \pm 9 \\
191 \pm 8 \\
232 \pm 17 \\
273 \pm 13 \\
286 \pm 8\end{array}$ & $\begin{array}{r}51 \pm 3 \\
72 \pm 5 \\
94 \pm 7 \\
143 \pm 9 \\
191 \pm 11 \\
228 \pm 14 \\
273 \pm 14 \\
279 \pm 17\end{array}$ \\
\hline
\end{tabular}


regularly with age without any difference between the two groups of rats. The wet weights of normal testes (fig. 1) showed a sustained development until 67 days of age and a lesser growth thereafter. Compared with normal testes, the irradiated testes were lighter from days 32 to 53 (significant difference only at days $32: P<0.01$, and $39: P<0.05$ ) and significantly lighter from 60 to 81 days of age, but with a similar pattern of general increase.

Interstitial fluid (IF). - Until 67 days of age, the volume of IF recovered from normal and irradiated testes increased regularly with age and in a pattern similar to the growth of the corresponding testes with a significant difference at days 32 and 60 . At days 74 and 81 , IF from both types of testes decreased regularly whilst their corresponding weights increased (fig. 1).



FIG. 1. - Age changes in interstitial fluid secretion and testis weight in rats after unilateral irradiation of the right testis. 
Tubular fluid (TF). - In normal testes (fig. 2), TF increased regularly between 32 and 53 days of age, then decreased sharply to 67 days and maintained this level until day 81 . In irradiated testes, TF production changed in a way similar to that of normal testes but with the following differences:

- between days 32 and 46, TF production was always greater with a significant difference at day $39(P<0.001)$;

- at day 53, the day of maximum secretion, production was signicantly lower $(P<0.01)$;

- at day 60 , TF was greater but declined beyond this age to a lower but nonsignificant level.

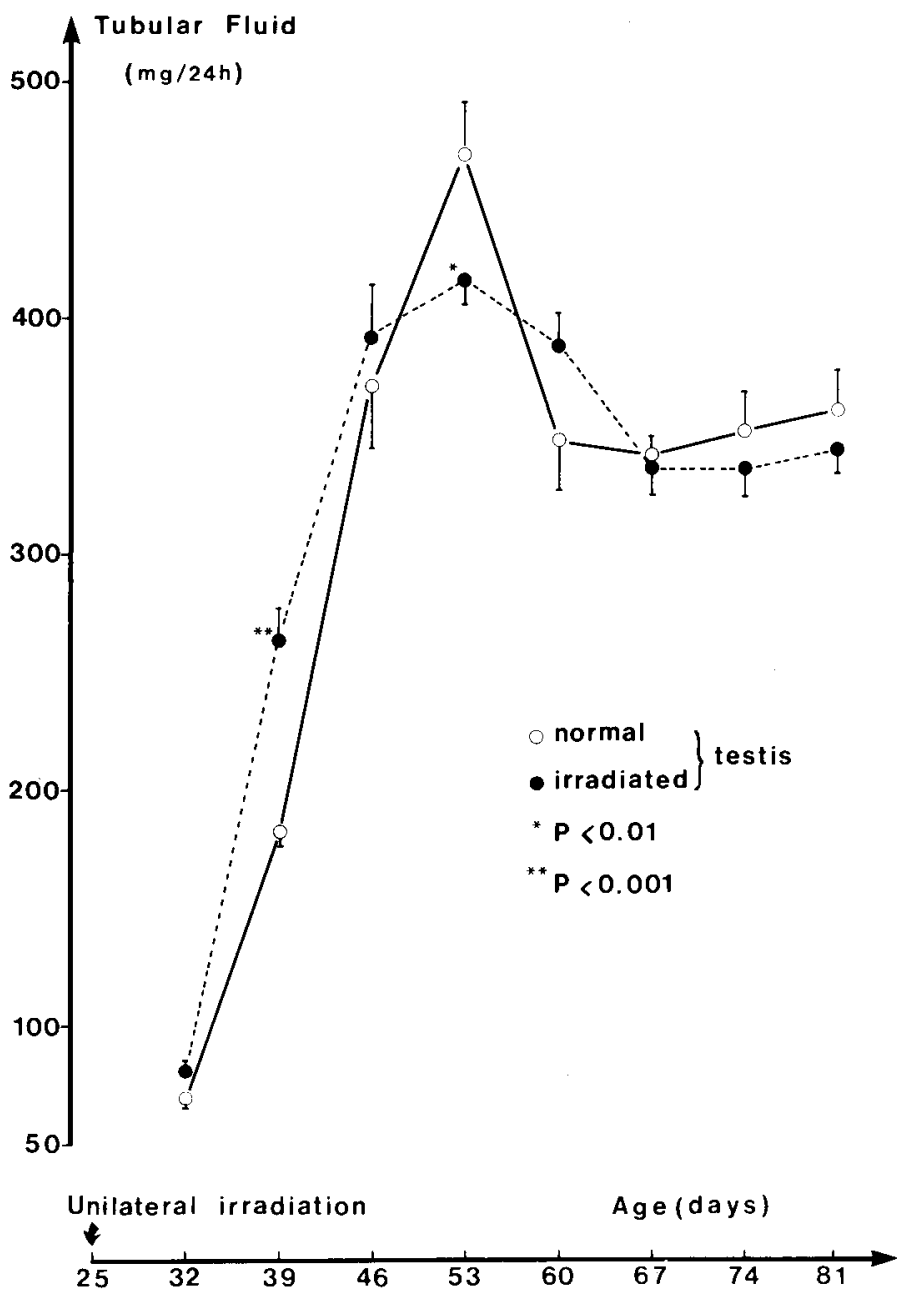

FIG. 2. - Age changes in tubular fluid secretion in rats after unilateral irradiation of the right testis. 


\section{Discussion.}

Testicular weight. - Sertoli cells lose their capacity for mitosis by the 15th post-natal day in rats (Clermont and Perey, 1957 ; Nagy, 1970). When fully differentiated by the 25-30th postnatal day, the Sertoli cells become highly refractory to ionizing radiation (Fogg and Cowing, 1951) so that the effects of $X$ ray on testicular weight can be ascribed solely to effects on germ cells (Erikson and Blend, 1976). It is well stated that the most radiation-sensitive cells of the testis occur among the heterogeneous populations of A spermatogonia (Oakberg, 1975). Therefore, the differences in weight between control and irradiated testes at various times after unilateral irradiation could be interpreted as follows :

- at day 32 , a week after irradiation, the loss in testicular weight might reflect a net spermatogonial killing ;

- at days 39, 46 and 53, the progressive disappearance of the significant difference between the weight of the two types of testes would suppose a compensatory mechanism of repopulation, perhaps due to less natural degenerescence of the spermatogonia (Huckins, 1978) and/or to intensive mitosis of surviving spermatogonia (Oakberg, 1975) ;

- at days 60 and 67 , the sharp decrease of the weight of the irradiated testes might reflect the depletion of spermatocytes, corresponding to the killing of spermatogonia 5 weeks before;

- at days 74 and 81 , the differences in weight between the irradiated and normal testes remained significant but lower in magnitude than at earlier ages. This would confirm the probable spermatogonial repopulation of the seminiferous tubules between days 39 and 53, inducing improved spermatogenesis several weeks later.

Testicular fluids. - Before 25 days of age, the production of TF by the rat testis is known to be under the specific control of FSH (Setchell et al., 1973) and that of IF under the control of LH and/or hCG (Sharpe, 1979, 1980 ; Jegou et al., 1982). Beyond this age, it is not known whether IF remains sensitive to $\mathrm{LH}$ or hCG, and the hormonal regulation of TF is poorly understood (Setchell, 1978; Waites and Gladwell, 1982).

1. Interstitial fluid: the liquid collected by allowing fluid to drain from the incised testis is an accurate reflection of changes in total extracellular fluid volume (Sharpe and Cooper, 1983) and represents modifications in the permeability of testicular capillaries (Setchell and Sharpe, 1981). The volume of recovered interstitial fluid increased in parallel with testicular weight until 67 days of age in our Wistar rats and until 80 days in Sprague-Dawley rats studied by Sharpe and Cooper (1983). In the present study, when the weight of the irradiated testes was significantly lower than that of the normal testes, so was IF production. Furthermore, when the weight of the irradiated testes was no longer significantly lower than that of the normal testes, as at days 45 and 53 , IF production in the two testes was similar. These results together would seem to show that, at least during puberty, there exists a metabolic relationship between the extratubular 
fluid (and therefore capillary permeability) and the germinal population of the testes. This cooperation seemed to disappear in maturing rats, as observed at days 74 and 81 when IF from normal and irradiated testes decreased although the weight of the corresponding testes continued to increase, but at a slower rate than in the pubertal period. It is more difficult to explain this latter result which could be due to a normal age change in the capillary permeability of the testes (perhaps under the influence of $\mathrm{FSH}, \mathrm{LH}$ and testosterone which all decrease with age : Ketelslegers et al., 1978 ; Jegou et al., 1982) and to the stabilization of spermatogenesis, as shown by the plateau in testicular weight during maturation (Ortavant et al., 1968 ; Ketelslegers et al., 1978).

Nevertheless, the similarity of the changes in normal and irradiated testes would argue against the direct effect of irradiation on the capillaries, as already advanced by Wang et al. (1983).

2. Tubular fluid: fluid production by rat seminiferous tubules commences between days 15 and 20 after birth (Jegou et al., 1982). After efferent duct ligation, the fluid accumulated in the testis during a given period is currently called " testicular fluid " and could be thought to be the sum of intratubular (TF) and extratubular (IF) fluids. We have previously shown (Laporte et al., 1985) that after efferent duct ligation in adult rats, changes in testicular fluid secretion reflect only changes in tubular fluid secretion. In the present work, the differing patterns of production of these two fluids during puberty sustain this viewpoint. Our experimental design used unilateral testicular irradiation so as to avoid any systemic hormonal influence when studying local germinal cell regulation of Sertoli cell fluid secretion in growing rats. We believe our results to be relevant to two local regulatory mechanisms.

2.1. Quantitative regulation. Fluid production increased with age and spermatogenetic development in both irradiated and normal testes and reached a maximal level at day 53 after birth, the age at which $100 \%$ of normal seminiferous tubules show a complete spermatogenesis (Demoulin et al., 1981). This result, obtained using a method whereby the two testes are not in the same state, agrees well with our previous results in normal rats (peak at 55 days: Laporte and Gillet, 1984) and to a lesser extent with those of other authors (peak at 45 days: Setchell, $1970 ; 60$ days : Jegou et al., 1982). Since the same method (Smith, 1962) was used by all authors, the differences between them can probably be accounted for by the strain of rat used. When spermatogenesis is deficient, for example after in utero busulfan treatment, TF production does not increase with age during the pubertal period, but there is a weak and constant secretion of fluid (Laporte and Gillet, 1984). Both results support the idea of a relationship between the quantitative size of the germinal cell population and tubular fluid secretion, as previously described for tubular diameter (Gillet and Laporte, 1973). Consequently, the germ cells seem to activate Sertoli cell metabolism, inducing a greater secretion of fluid (Waites and Gladwell, 1982). Such a metabolic influence has already been described for the carbohydrate metabolism of Sertoli cells (Jutte, 1982). 


\subsection{Qualitative regulation}

2.2.1. Stimulatory effect : It is surprising that the irradiated testes produced more TF during pubertal development with a significant difference at day 39 $(P<0.001)$, two weeks after irradiation, at the time when the weight of the testes was significantly lower than that of the control testes $(P<0.05)$ and spermatogonial repopulation might occur. Consequently, this increased TF production cannot be explained solely by the metabolic influence of the germ cells. Diploid cell (spermatogonial) secretory factor(s) may affect TF secretion in a way comparable to the stimulatory influence of some stages of the spermatogenic cycle on Sertoli cell secretion of ABP (Parvinen et al., 1980 ; Purvis and Hansson, 1981). The same observation has been made in regard to plasminogen secretion both in vivo (Lacroix et al., 1981) and in vitro (Vihko et al., 1984).

2.2.2. Inhibitory effect : In both normal and irradiated testes, tubular fluid secretion decreased sharply and very significantly $(P<0.001)$ between days 53 and 67 of age, as previously observed in normal rats (Laporte and Gillet, 1984), and stabilized after this age.

In adult rats, a significant increase in tubular fluid secretion was observed concurrent with the disappearance of spermatids 45 days after busulfan treatment (Laporte and Gillet, 1975) or after testicular irradiation (Laporte et al., 1985). On the contrary, TF returned to normal levels when normal spermatogenesis was reestablished. These observations suggest the inhibitory influence of germ cells (probably haploid cells) on tubular fluid secretion in adulthood and the predominance of this qualitative regulation over quantitative regulation.

Figure 3 illustrates three possible modes of germ cell regulation of Sertoli

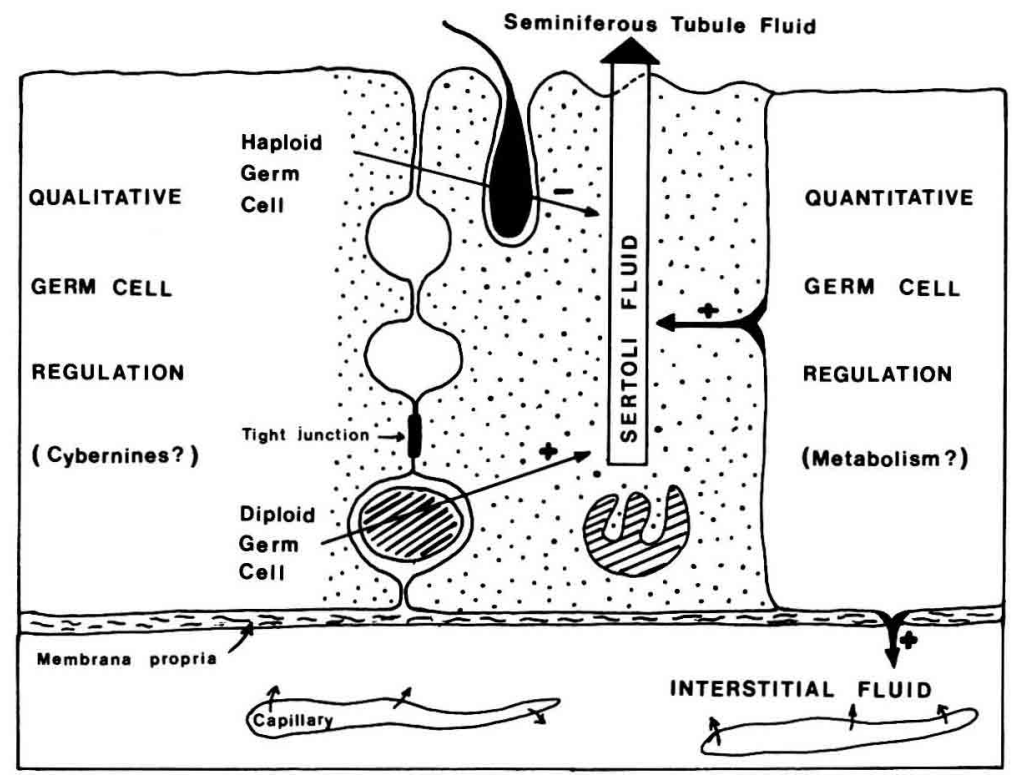

FIG. 3. - Hypothetical model of the regulation of Sertoli cell fluid secretion and interstitial fluid production by germ cells in growing rats. 
fluid secretion in growing rats, keeping in mind that, in adult rats, the inhibitory influence of spermiogenic cells may predominate. For interstitial fluid, only the possibility of a metabolic cooperation with germ cells emerges from our study.

Reçu en juillet 1984.

Accepté en octobre 1984.

Acknowledgements. - This work was supported by grants from « Délégation Générale à la Recherche Scientifique et Technique " (DGRST-80-02). We wish to thank M. Terriot for the illustrations, the secretary for typing the manuscript and M.R.J. Kilgour for correcting the English.

Résumé. Production comparée des fluides tubulaire et interstitiel chez le rat en croissance soumis à une irradiation testiculaire unilatérale.

Au cours du développement pubertaire, les productions de fluide tubulaire (TF) et interstitiel (IF) des testicules normaux et irradiés ont été suivies chez des rats soumis, à l'âge de 25 jours, à une irradiation testiculaire unilatérale droite. IF a été recueilli selon la méthode de Sharpe (1977) et TF déterminé par une variante personnelle de celle de Smith (1962), adaptée aux animaux dont les deux testicules sont dans un état physiologique différent (Laporte et al., 1985). Douze rats furent sacrifiés chaque semaine, pendant 8 semaines, du $32^{\mathrm{e}}$ au $81^{\mathrm{e}}$ jour. Dans les gonades protégées et irradiées, IF augmente parallèlement au poids des testicules respectifs jusqu'au $67^{\mathrm{e}}$ jour et diminue sensiblement après. II semble donc que l'irradiation n'affecte pas la perméabilité des vaisseaux capillaires et que le fluide extracellulaire s'adapte aux besoins métaboliques de la population germinale. Dans les testicules protégés, TF augmente significativement du $32^{\circ}$ au $53^{\circ}$ jour, diminue significativement jusqu'au 67 e jour et se stabilise ensuite. Le TF des testicules irradiés évolue d'une manière semblable mais avec des différences parfois significatives : une plus grande sécrétion du $32^{\mathrm{e}}$ au $46^{\mathrm{e}}$ jour, un maximum moins élevé au $53^{\mathrm{e}}$ jour et un niveau légèrement inférieur au témoin à la maturité. Ces résultats, ainsi que nos résultats antérieurs chez le rat adulte suggèrent, chez le rat en croissance, l'existence de plusieurs interactions possibles entre la lignée germinale et la lignée sertolienne, sécrétrice du fluide : une relation quantitative, d'ordre métabolique à l'instar de ce qui est observé pour IF et une double régulation qualitative, positive émanant probablement des cellules germinales basales (spermatogonies) et négative en rapport probablement avec les cellules haploïdes. Chez le rat adulte, la régulation qualitative semble l'emporter sur la régulation quantitative.

\section{References}

CLERMONT Y., PEREY B., 1957. Quantitative study of the cell population of the seminiferous tubules in immature rats. Amer. J. Anat., 100, 241-260.

DEMOULIN A., HUSTIN J., LAMBOTTE R., FRANCHIMONT P., 1981. Effect of inhibin on testicular function, 327-342. In FRANCHIMONT P., CHANNING C. P., Intragonadal regulation of reproduction. Acad. Press.

ERICKSON B. H., BLEND M. J., 1976. Response of the Sertoli cell and stem germ cell to ${ }^{60} \mathrm{Co}-\gamma$-radiation (dose and dose rate) in testes of immature rats. Biol. Reprod., 14, 641-650.

FOGG I. C., COWING R. F., 1951. The changes in cell morphology and histochemistry of the testis following irradiation and their relation to other induced testicular changes. Cancer Res., 11, 23-28. 
GILLET J., LAPORTE P., 1973. Action du busulfar, et de FSH sur le tube séminifère du rat: effets morphologiques et cellulaires. Arch. Anat. micr. Morphol. exper., 62, 385-398.

HUCKINS C., 1978. Behavior of stem cell spermatogonia in the adult rat irradiated testis. Biol. Reprod., 19, 747-760.

JEGOU B., LE GAC F., de KRETSER D. M., 1982. Seminiferous tubule fluid and interstitial fluid production. 1. Effects of age and hormonal regulation in immature rats. Biol. Reprod., 27. 590-595.

JUTTE N., 1982. Changes in carbohydrate metabolism during development of germ cells, 49-54. In JUTTE N., Role of carbohydrate metabolism in hormonal regulation of spermatogenesis. Ph. D. Erasmus Univ. Rotterdam.

KETELSLEgers J. M., HETZEL W. D., SHERINS R. T., CATT K. J., 1978. Developmental changes in testicular gonadotropin receptors, plasma gonadotropins and plasma testosterone in the rat. Endocrinology, 103, 212-222.

LACROIX M., PARVINEN M., FRITZ I. B., 1981. Localization of testicular plasminogen activator in discrete portions (stages VII and VIII) of the seminiferous tubule. Biol. Reprod., 25 , 143-146.

LAPORTE P., 1979. Evolution physiologique et facteurs de variations des acides sialiques dans l'unité testiculo-épididymaire et du fluide dans le testicule chez le rat normal et aspermatogène. Th. Doct. ès Sci., Univ. Poitiers, $n^{\circ} 290$.

LAPORTE P., GILLET J., 1975. Influence de la spermatogenèse sur la secrétion du fluide testiculaire chez le rat adulte. C.R. Acad. Sci. Paris, D, 281, 1397-1400.

LAPORTE P., GILLET J., 1984. Changes with age in the testicular fluid secretion of normal and aspermatogenic rats. I.R.C.S. Med. Sci., 12, 54-55.

LAPORTE P., VIGUIER-MARTINEZ M. C., ZONGO D., LE FLOCH O., LIPINSKI F., 1985. Changes in testicular fluid production and plasma hormones in the adult rat after testicular ${ }^{60} \mathrm{Co}$ irradiation. Reprod. Nutr. Dévelop., 25, 355-366.

NAGY F., 1970. Cell division kinetics and DNA synthesis in immature Sertoli cells of the rat testis. J. Reprod. Fert., 28, 389-395.

OAKBERG E. F., 1975. Effects of radiation on the testis, 233-243. In JOHNSON A. D., GOMES W. R., Handbook of Physiology, Vol. 5, Acad. Press, New York.

ORTAVANT R., COUROT M., de REVIERS M. M., 1968. Activités spécifiques des différentes FSH et LH sur le testicule des mammifères, 369-380. In La spécificité zoologique des hormones hypophysaires et de leurs activités. Coll. CNRS, Paris, $\mathrm{N}^{0} 117$.

PARVINEN M., MARANA R., ROBERTSON D. M., HANSSON V., RITZEN E. M., 1980. Functional cycle of rat Sertoli cells : differential binding and action of FSH at various stages of spermatogenis cycle, 424-432. In A. STEINBERGER, E. STEINBERGER, Testicular development, structure and function. Raven Press, New York.

PURVIS K., HANSSON V., 1981. Hormonal regulation of spermatogenesis. Regulation of target cell response. Int. J. Androl., Suppl. 3, 83-143.

SETCHELL B. P., 1970. The secretion of fluid by the testis of rats, rams and goats with some observations on the effect of age, cryptorchidism and hypophysectomy. J. Reprod. Fert., 23, 79-85.

SETCHELL B. P., 1978. Naturally occurring and induced dysfunctions of the testis, 359-432. In SETCHELL B. P., The mammalian testis. Eds Paul Eleck, London.

SETCHELL B. P., DUGGAN M. C., EVANS R. W., 1973. The effect of gonadotrophins on fluid secretion and sperm production by the rat and hamster testis. J. Endocr., 56, 27-36.

SETCHELL B. P., SHARPE R. M., 1981. Effect on injected hCG on capillary permeability, extracellular fluid volume and the flow of lymph and blood in the testes of rat. $J$. Endocr., 91, 245-254.

SHARPE R. M., 1977. Relationship between testosterone, fluid content and luteinizing hormone receptors in the rat testis. Biochem. Biophys. Res. Commun., 75, 711-717.

SHARPE R. M., 1979. Gonadotropin-induced accumulation of interstitial fluid in the rat testis. J. Reprod. Fert., 55, 365-371.

SHARPE R. M., 1980. The temporal relationship between interstitial fluid accumulation and changes in gonadotropin-receptor numbers and steroidogenesis in the rat testis. Biol. Reprod., 22, 851-857. 
SHARPE R. M., COOPER I., 1983. Testicular interstitial fluid as a monitor for changes in the intratesticular environment in the rat. $J$. Reprod. Fert., 69, 125-135.

SMITH G., 1962. The effects of ligation of vasa efferentia and vasectomy on testicular function in the adult rat. $J$. Endocr., 23, 385-399.

VIHKO K. K., SUOMINEN J. J. O., PARVINEN M., 1984. Cellular control of plasminogen activator secretion during spermatogenesis, p. 76. In 3rd European Workshop on molecular and cellular endocrinology of the testis. Lyon, France.

WAITES G. M. H., GLADWELL R. T., 1982. Physiological significance of fluid secretion in the testis and blood-testis barrier. Physiol. Rev., 62, 624-655.

WANG J., GALIL K. A. A., SETCHELL B. P., 1983. Changes in testicular blood flow and testosterone production during aspermatogenesis after irradiation. $J$. Endocr., 98, 35-46. 